\title{
Telling the true Gibraltarian Story: an Interview with Gibraltarian writer M.G. Sanchez
}

\author{
Elena Seoane \\ University of Vigo \\ elena.seoane@uvigo.es
}

Born in Gibraltar in 1968, writer M. G. Sanchez moved to the UK to study English Literature at the age of twenty-seven, where he has lived ever since, with interludes in New Zealand (2004), India (2005-2008) and, more recently, Japan (2014-2016). He took BA, MA and PhD degrees at the University of Leeds, completing his studies in 2004 with a thesis exploring perceptions of 'hispanicity' in Elizabethan and Jacobean literature. His first publication was Rock Black: Ten Gibraltarian Stories, a collection of short narratives. Since then he has written three novels on Gibraltar - The Escape Artist, Solitude House and Jonathan Gallardo - as well as numerous stories and essays. His latest work, Past: A Memoir, was published in October 2016, and explores his own family history on the Rock.

Elena Seoane: Mark, our research group Variation in English Worldwide (ViEW) at the University of Vigo is compiling a corpus of Gibraltar English as part of the International Corpus of English. As sociolinguists we are fascinated by the complexity and depth of Gibraltarian identity, what you have sometimes called 'Gibraltarianness.' In the British political and cultural magazine The New Statesman (17/2/2016) you say that "if you don't write your stories, others will." Is this what first drew you to write about Gibraltar identity and culture?

Mark G. Sanchez: Yes, absolutely. I think that it is tremendously important for us as Gibraltarians to have our own stories out there in the public domain. If we don't, then there is always a danger that people will start believing the myths and propagandistic distortions that are often told about us. I'll give you a small example of what I mean, 
Elena. In the late 80 s I was a student at the University of Manchester. While there I became friends with a female student from La Línea de la Concepción. One day she introduced me to a friend of hers from Madrid. When he heard that I was from Gibraltar, this guy became angry and aggressive, saying that there was no such thing as a Gibraltarian because the real Gibraltarians had escaped to Spain when the Rock fell to the British in 1704. 'Then what am I exactly?' I asked him, completely taken aback by his tone. 'Tu, amigo mio,' he replied, 'eres un colono.' ('You, my friend, are a settler.') Can you imagine this sort of situation? There I am, in the middle of Manchester, when this boy from Madrid, who has never come anywhere near Gibraltar in his life, starts telling me that I don't have a right to call myself Gibraltarian. An irony of ironies, considering that I can trace my family history on the Rock back to the mid-1780s!

ES: Was that the moment when you decided, 'This is it: I have to start writing about Gibraltar'?

MGS: No, that came a few years later, in the mid-1990s, when Britain and Spain were going through one of their periodic 'spats' over the Rock. Gibraltar was continually in the news at the time (as it has been recently) and every day I kept hearing the same old journalistic clichés about us. That we were as Spanish as a 'dish of paella.' That we were nothing but a bunch of tax-evading UK expats. That we were "más andaluces que los andaluces." 'This isn't right,' I thought. Someone has to stand up and tell the Gibraltarian story from our own perspective, to counter the lies and crude oversimplifications that are being peddled about us by the political press. I think this was the actual point when I decided to take the plunge and start writing specifically Gibraltarian stories.

ES: In a number of talks in Italy, Switzerland and Spain, you have mentioned that stories play an essential role in identity formation and self-definition. I assume that your narrative rendition of Gibraltarian identity is manifold. How do the characters of your novel contribute to the formation of Gibraltarian identity?

MGS: I think national identity is always a very difficult subject to address, Elena, as it is tied into all kinds of subjectivities. Sure, there are certain linguistic and sociobehavioural traits that define us as Spaniards or Englishmen or Frenchmen or Gibraltarian or whatever - but at the same time there are no fixed rules for calibrating nationality, nothing set in stone, as it were. What I am interested, above all, as a Gibraltarian writer is to capture the reality of everyday life on the Rock, all the countless little peculiarities associated with living in a small, hemmed-in place where practically everybody knows each other. By focusing on the quotidian in this manner, I hope to show how life on the Rock differs, say, from life across the border in La Línea de la Concepción, or, for that matter, in a comparably sized town in mainland Britain. I hope to show, in other words, that we have our own Gibraltarian way of thinking and doing things. 
ES: In your latest book, though, you delve into your own family history to try to explain what it means to be Gibraltarian, don't you?

MGS: Yes, that is correct - in October this year I published a memoir about the events in the summer of 2013, when my father died of a heart attack while cycling on the Spanish side of the border and we had to repatriate him in the middle of what, in retrospect, was probably the worst 'border crisis' in the last thirty years. In a certain sense, the memoir can be viewed as a tribute to his memory, but I also wanted to take the opportunity to repudiate some of the criticism that is often hurled at Gibraltarians by some sectors of the Spanish nationalist press, particularly the idea that we are 'colonos' with no right to the land under our feet. I've heard it again and again - this idea that we are no more than land-grabbing 'colonos' who have only been living in Gibraltar for a handful of years - and it's just so unfair. That is why I talk about my own family background in the new book. Specifically, I look at my four grandparents and at which point their ancestors came to the Rock. On my mother's side there are the Whitelocks, who came over from England in the mid-1780s, and the Schembris, who arrived in 1861 from Malta. A similar story can be seen on my father's side, with the Sanchezes coming from Spain in 1805, and the Duartes from Portugal around 1820. Nor is my family story unique in this way. Most people on the Rock have similarly mixed bloodlines.

ES: A lot has been written about your work, and some expressions used to describe it are "relentlessly brutal", "utterly credible" (Prof. John Stotesbury, Professor of Eastern Finland University) and "truly shocking and abrupt" (Nicholas Rankin, British historian and Fellow of the Royal Society of Literature). What part of Gibraltar history needs to be brutally described? What are you - or Gibraltarians - resentful about?

MSG: I wouldn't say that I am resentful about anything in particular, but I don't like how there is so much interest in the sovereignty dispute between the UK and Spain what in Spain is commonly known as 'el contecioso de Gibraltar'- and yet so little interest in the people who actually live on the Rock. How can you focus so much attention on a place and yet not listen to the concerns and worries of the people who live there? To me that is just plain wrong.

ES: I've noticed that the border between Spain and Gibraltar plays a central - one might even say dominant - role within your writing. Is it one of your missions as a writer to let people know what is happening at the border?

MGS: Yes, absolutely. Most people know the border from occasional footage shown on the national news, but the reality cannot easily be fitted within the parameters of a twoor three-minute news clip. Like all boundary zones, it is a space riddled with complications and inconsistences, a real-life Pandora's box, and what you experience 
there one day might be in total contrast to what you experience the next. I am reminded to a certain degree of what the American author Janette Turner Hospital says in one of her novels. "At borders," she writes, "no amount of prior planning will necessarily avail... In the nature of things, control is not in the hands of the traveler." These lines were written specifically about the Canadian-American border, but they could easily apply to the border between Gibraltar and Spain. If the relationship between Britain and Spain is fluid and stable, then you can cross the border in less than a minute. But if it is bad, it directly influences the set-up at the border and you could be trapped there for hours on end. When my father died in Spain 2013 and we had to repatriate him, for instance, we had to deal with all kinds of border-related problems: three- or four-hourlong traffic queues, overzealous guardia civiles, all sorts of unnecessary red tape. In fact, the experience was so traumatic for me personally that I developed a type of mental block and for three years I couldn't bring myself to go anywhere near that border. Yet when I finally crossed the border again earlier this year, would you believe, I was able to walk through without anybody even checking my passport! I think unpredictability is hard-wired into the place!

ES: Mark, of all the stereotypes about Gibraltar you've heard in your life, which one is the most outrageous of all, the one that is way out of line, insensitive or downright ignorant?

MGS: That's a hard question. The truth is that I've heard all kinds of things in my time. That we're all a bunch of smugglers and money-launderers, for example. That we are no more than a town of renegade Andalusians. That nobody lives on the Rock apart from British military personnel. That Gibraltar is full of reactionary British expats who are there to avoid paying tax in the UK. That the Gibraltarian government is out to purposefully damage the Spanish economy. That we are a bunch of parasites sucking the lifeblood out of Spain. I could go on and on and on. If I had a pound for every distortion and propagandistic fiction I've heard about Gibraltar, I'd be considerably better off than I am now!

ES: In your novel The Escape Artist, the protagonist says that "in the nineteenthcentury everybody used to call us "mongrels" because we were neither Spanish nor British, but a strange composite of the two with a bit of Genoese, Maltese, Irish, Portuguese and Jewish thrown into the melting pot as well". (Sanchez 2013: 13). The hybrid nature of Gibraltarian identity is unquestionable, but is it crucial to understand Gibraltarainness today?

MSG: Yes, I think hybridity is a key word when it comes to understanding Gibraltarian identity or 'Gibraltarianness.' We are neither fish nor fowl, as the English saying goes, but an amalgam of the two. It's like when you mix two colours and end up with a completely different one. To understand modern-day Gibraltar you have to understand this sense of hybridity and all the apparent craziness that comes with it - blond-haired 
people with Spanish surnames, red pillar boxes beside chiringuitos serving gambas a la plancha, British bobbies speaking Spanish, et cetera, et cetera. I think this is what makes as unique and hard to categorise - the way we straddle two very different European cultures and bring them together in our mannerisms and behaviour.

ES: In a recent essay written for a conference at the University of Basel (8/9/2016) you talk about a hardening of attitudes towards foreigners and outsiders after the Brexit referendum. You also mention several racist incidents that you have suffered in your own person. Has all this ever made you question your own sense of British Gibraltarian identity?

MGS: Well, it's never pleasant to be marginalized purely on account of one's accent, but, sadly, incidents of this sort are all too common nowadays. People want conformity, sameness, and anyone who doesn't outwardly appear to belong to a national collective is automatically repudiated. We saw this in the aftermath of the Brexit referendum and we are also seeing it in the US following Trump's presidential election. Just this morning I was looking at the news and I saw an article about fake news on Facebook and another which said that 'post-truth' has been declared the international word of the year by the Oxford dictionaries. I thought to myself, 'What sort of a world are we creating here?'

ES: So from this I take it that you see Brexit as a very negative development?

MGS: For me Brexit is an incredibly retrograde and disappointing step and a decision that will bring long-term economic and political instability to both Britain and Gibraltar. I think sooner or later the people of the UK will lament the day that they fell for the divisive xenophobic rhetoric promoted by Nigel Farage and other members of the 'Leave Campaign.' As for Gibraltar, who knows how Brexit might affect us? Some right-wing politicians in Spain see Brexit as an opportunity to pressure the Gibraltarians into relinquishing their long-standing links with Britain, and one or two individuals have even gone as far as saying that the time has come for the border to be shut again. If you ask me, Brexit is bad for everybody - Gibraltar, the UK, and even Europe as a whole.

ES: Some exclusively linguistic questions now, if I may. According to the literature (Levey 2008, Weston 2013), the sociolinguistic landscape of Gibraltar is age-graded, divided into four distinct groups according to age. You belong to the 2nd generation, in which - according to them - the language of communication is Yanito and Spanish. English would be for you a 'high language', and, given the frequent exposure to it you would switch frequently from Spanish to Yanito and to English. Is this true in your case (when you are in Gibraltar) or is it also a question of education and profession? 
MGS: As in most places, education and profession do influence the way that people speak, but I think that Weston and Levey are correct: the sociolinguistic landscape in Gibraltar is very much age-graded. Generally speaking, the older the person is, the less comfortable they will be speaking English. My grandmother, for instance, used to tell me that, when we she was in London during the years of the evacuation (1941-1945), some of her Gibraltarian compatriots had such poor command of the language that they used to say 'Todo te lo dan con Ron' when catching a bus and telling the bus driver they were heading towards Tottenham Court Road! The reason her generation had so much trouble speaking English was that in the 1930s and 1940s Gibraltar was still very much caught up in a colonial mindset. We had British administrators holding all the top jobs in Gibraltar, with the local civilians doing all the menial jobs under them. To maintain the status quo, British colonial administrators deliberately undereducated their subjects, hoping by doing this to keep them 'in their place.' After the war, however, there was a radical change in the way the British government viewed education in the colonies. Greater emphasis was placed on self-development and more structured curriculums were drawn up. The generation that grew up in this new climate (my parent's generation and to a certain extent my own) was much more fluent in English and could shift between both languages in a way that their forefathers would have found impossible. Now, of course, we have a completely new generation - one that speaks mostly in English and hardly switches into Spanish. They understand Spanish, yes, but they seem to be very reluctant to speak it. It's almost like they have turned into the very opposite of their great-grandparents!

ES: A lot has been written about llanito, which is a form of Spanish interspersed with English words and loanwords from other Mediterranean dialects and languages. Could you tell us something about it?

MGS: To an untrained ear, llanito sounds similar to the type of Spanish spoken in southern Andalusia, but if you listen carefully you will hear plenty of interpolations, as well as lots of code-switching. There are also many anglicisms in llanito - that is to say, English words which have been modified phonetically to sound 'more Spanish.' Some well-known examples are 'mebli' ('marble'), 'kayki' (for 'cake'), 'bateria' ('battery'.) To give things even more of a complicated twist, there are some words in llanito which have been imported directly from Portuguese and Italian by way of the migrants who came to Gibraltar in the nineteenth century. A famous example is the Genovese word 'marciapê', which is how you would refer in llanito to an English 'pavement', or 'Ia acera' in Spanish.

ES: We all modify the way we talk depending on our interlocutors and context. Linguists call it accommodation. Are you aware of using different English accents in different settings within Gibraltar? 
MSG: I wouldn't necessarily put on a different accent, but I would modify the amount of English/Spanish words that I use depending on who I'm speaking to. If I were talking to a labourer or some other blue-collar worker, for instance, I'd probably use more Spanish words than English ones. Alternatively, if I were talking to a judge or a lawyer or a university professor, I would modify the balance so that almost all my words would be English ones. Of course, to a certain extent I am generalizing when I say all this since there are labourers in Gibraltar who speak exclusively in English and, conversely, there are lawyers who prefer conversing in Spanish. But as a general rule, yes, I would change how I speak depending on who is there before me.

ES: I live in Galicia, a bilingual community, Galician/Spanish. In the past, the situation was diglossic, with Spanish being the language of prestige and Galician being the language of rural areas to use only at home. Younger generations now do not feel that difference, because Galician is empowered by the regional government. Does this diglossic situation exist in Gibraltar, whereby Spanish would be the 'low language' and English the 'high' one?

MGS: Traditionally, yes - English in Gibraltar has been seen as the language of prestige, whereas Spanish could be described as 'el lenguaje de la calle' ('the language of the streets'). There are very specific historical and political reasons for this. Until relatively recently, as I explained earlier, institutions and government departments were run by English expatriate civil servants and this ensured that Gibraltarians needed to speak good English to attain respectable jobs. Nowadays, of course, the situation is very different: Gibraltar has a large degree of political and juridical autonomy and most top jobs are done by Gibraltarians. From this, you'd assume that it is no longer as important to speak good English as it was in the old days, but in fact it's quite the reverse: English is even more of a prestige language now than it was in the old 'colonial days.' Many young parents, for example, speak to their children only in English - even though amongst themselves they would speak in llanito! It's a bizarre situation and one that I find a little frustrating. I think part of the explanation for it is that old habits die hard, but another part is that the relationship between Gibraltar and Spain has been very problematic in the last few years and, as a result, people are subconsciously turning away from the Spanish language, which of course is a real, real shame, as it is always better to be bilingual than monolingual.

ES: So do you think that the use of Spanish in Gibraltar will eventually disappear altogether?

MGS: I hope not, but when you consider how Gibraltar has always been in a state of linguistic flux, who knows? Personally, I would feel very sad if Spanish disappeared altogether from the Rock because I consider both the English and Spanish languages as part of my Gibraltarian heritage. 
ES: Finally, if anybody reading this interview would like to find out more about your writing, where should they look?

MGS: I recommend that they visit my website: www.mgsanchez.net or my facebook page www.facebook.com/mgsanchezwriter/.

ES: I'd like to thank you for your kindness to agree to this interview, and also your openness in answering my questions. We hope to have you at the University of Vigo in the spring semester 2017, but until then, we will be in touch regarding your work and opinions on Gibraltarianness.

\section{References}

Levey, David (2008): Language Change and Variation in Gibraltar. Amsterdam: John Benjamins.

Weston, David (2013): “Code-switching variation in Gibraltar". International Journal of Bilingualism, 17(1): 3-22. 